Historic, archived document

Do not assume content reflects current scientific knowledge, policies, or practices. 

1 1 $B$ FA

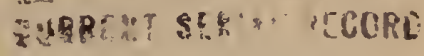

OCT 291948

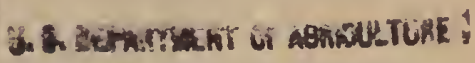

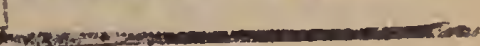

\section{FOREST RESOURCES OF} MISSOURI

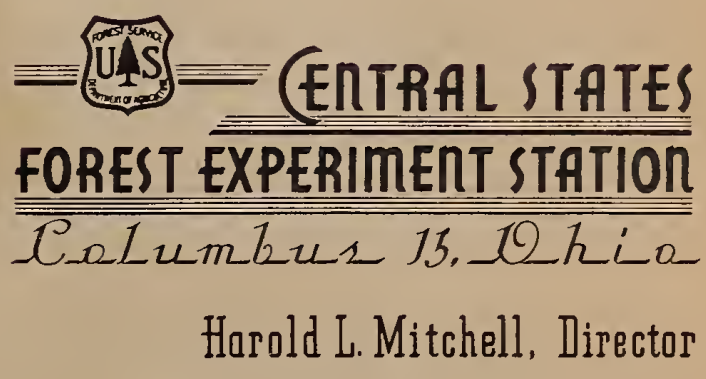




\section{FOREST RESOURCES}

$\mathrm{OF}$

\section{IIISSOURI}

BY

THE FOREST SURVEY ORGANIZÁTION

at the

Central States Forest Experiment Station

R. K, Winters, Chief, Division of Forest Economics E. V. Roberts, In Charge Forest Survey

The field work on which these statistics are based was done by the following men under the supervision of M. E. Becker.

$$
\begin{array}{ll}
\text { A. E. Block } & \text { P. F. Ehinger } \\
\text { J. I. Burkle } & \text { T. H. Hansen } \\
\text { C. R. Crowther } & \text { T. J. Schmitt } \\
\text { J. J. Cann } & \text { R. T. Train } \\
& \text { E. F. Van Arsdel }
\end{array}
$$

O. Y. Hutchison, Z. L. Quigley, and J. E. Wiggins did the photo interpreting rork under the direction of $\mathrm{K}$. F. Iloessner. The office compilations were made by rargaret Feirsol, Betty Quilligan, liary Lou Sterner, and Florence Karinen, uneer the supervision of Lake Coipton. G. I Schnur prepared the volume tables and determined the statistical accuracy of tabular figures. Virginia Tonlinson, Alberta Hiatt, and Bonnie Jo Jillians did the stensgraphic work, and $C$. $\mathbb{E}$. Hamm and $K$. W. Chrisener the crafting. 


\section{FOREWORD}

The Forest Survey is a Nation-wide activity of the Forest Service. The fivefold purpose of the Forest Survey is (I) to make a field inventory of the present supply of standing timber; (2) to ascertain the rate at which this supply is being increased through growth; (3) to determine the rate at which it is being diminished through industrial and domestic uses, windfall, fire, disease, and other causes; (4) to determine the present consumption and the probable future trend in requirernents for forest products; and (5) to interpret and correlate these findings with existing and anticipated economic conditions, as an aid in the formulation of both private and public policies for use of land suitable for forest production.

The Forest Survey is conducted in the various forest regions by the forest experiment stations of the Forest service. In Missouri, the project is directed by the Central States Forest Experiment Station with headquarters in Columbus, ohio. For Survey purposes, the state has been divided into five principal regions based on character of forest, topography, and other factors that influence tree growth.

Survey releases have been published for each of the regions (Forest Survey Releases 1 to 5 inclusive) presenting the more significant statistics on forest area and timber volume. This release summarizes these data for the state as a whole. In some instances figures for individual forest types and species may not exactly equal the totals obtained by adding the figures in the five regional releases. This is due to the fact that minor types and species were grouped differently in several of the regional releases and the state summary. Later an analytical report for the state will be published, which will interpret forest area, timber volume, growth, and drain statistics in the light of existing and anticipated economic conditions. This interpretation will focus attention on the principal forest problems and will suggest possible solutions. 


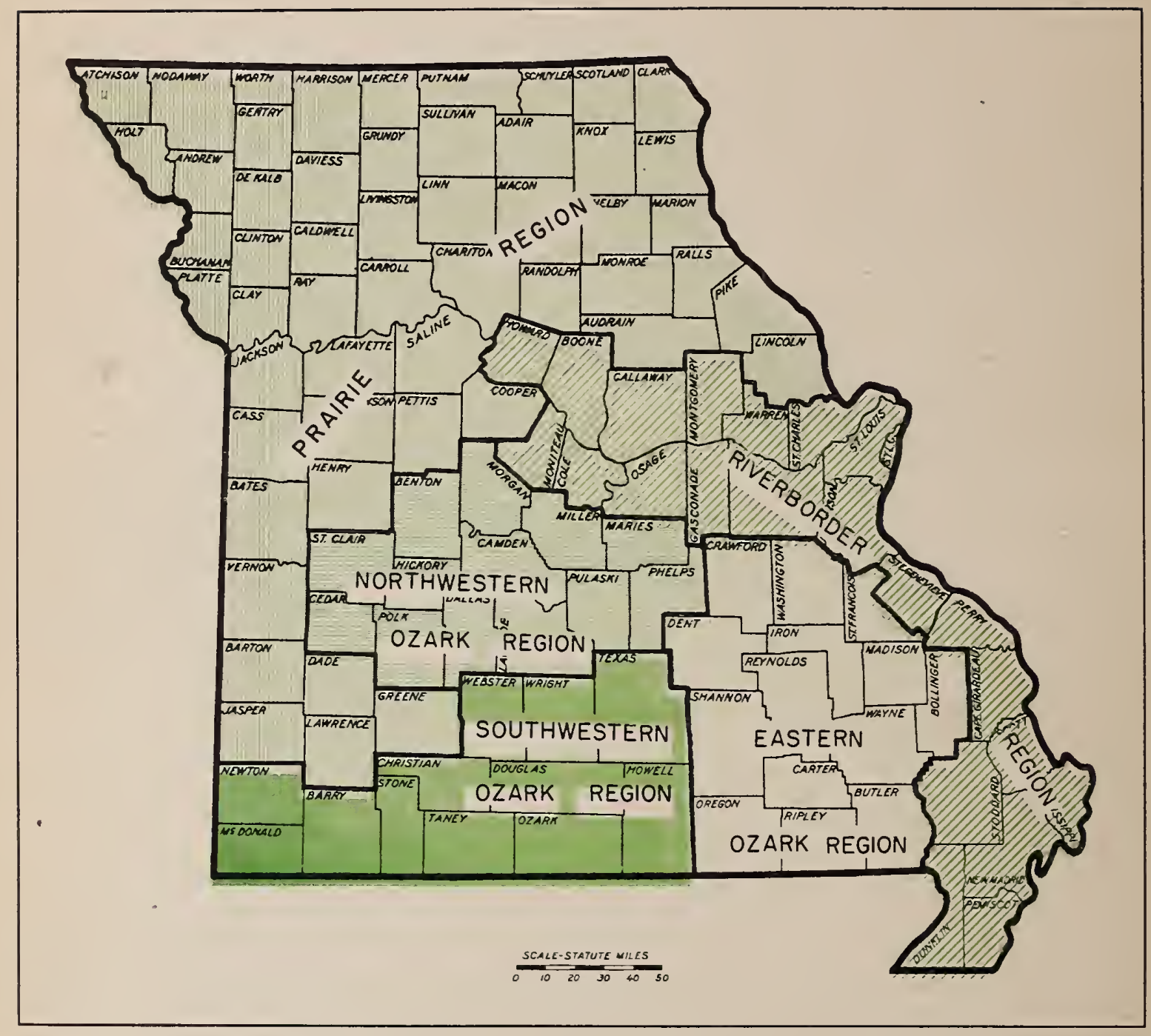

LOCATION OF FOREST SURVEY UNITS IN MISSOURI 


\section{SIGNIFICANT FACTS CONCERNING}

\section{THE FOREST RESOURCES OF MISSOURI}

The forests of Missouri occupy 15,187,000 acres or onethird of the land area of the state. The Ozark regions are most heavily forested, and contain more than two-thirds of the forest area. In the mountainous eastern 0zark region more than 70 percent of the area is forested and even in the less rugged western Ozark regions, forests cover more than half of the land area. In the Prairie region, forests are found on only 13 percent of the land area, and are chiefly confined to stream bottoms and the rougher portions of farms.

Ninety percent of the commercial forest area is privately owned. The Clark and the Mark Twain National Forests contain 8 percent of the commercial forest area and the remaining 2 percent is about equally divided between other federal and state ownerships.

The oak-hickory forest type is prevalent throughout the state and is found on nearly two-thirds of the forest area. Shortleaf pine, usually in mixture with oaks, occurs on 7 percent of the forest area, chiefly in the Eastern Ozark region. Contrary to the impression gained in driving the ridge roads of the Ozarks, scrub hardwood stands, including stands of blackjack oak, occupy less than 2 percent of the forest land.

Less than 14 percent of the forest area supports sufficient board-foot volume to be classed as saw timber. Pole-timber stands are found on 43 percent of the forest area, seedling and sapling stands on 32 percent, and poorly stocked stands on 12 percent.

The volume of saw timber in the state is 11.9 billion board feet. Nearly two-thirds of this volume is oak, with white oak and black oak the most abundant species. Shortleaf pine makes up 4 percent of the total volume.

Nearly half of the board-foot volume occurs on the 14 percent of the forest area supporting saw-timber stands. The remaining volume is in trees of sawlog size scattered throughout stands classified as pole timber, seedling and sapling, and poorly stocked. More than half of the boardfoot volume is in trees less than 15.0 inches in diameter. 
The cubic volume of pole-size trees and the sawlog portion of saw-timber trees is 4.4 billion cubic feet. The distribution of this volume among the species closely parallels that of the saw-timber volume, with the oak species again accounting for nearly two-thirds of the volume. More than half of the cubic volume is in trees less than 11.0 inches in diameter.

The average saw-timber volume per acre for the state is 789 board feet. Saw-timber stands average 2,840 board feet per acre. The Ozark regions show considerably less volume per acre than the Prairie and Riverborder regions.

The average cubic-foot volume per acre of pole-size trees and the sawlog portion of saw-timber trees is 289 cubic feet. Again the averages for the Prairie and Riverborder regions are. greater than those for the Ozark regions.

The total cubic volume of sound wood including the tops and limbs of hardwoods, the sound portion of cull trees, and trees of noncommercial species is 8.1 billion cubic feet. The sound wood in noncommercial species and cull trees makes up nearly one-third of the total cubic volume indicating the large proportion of the forest area occupied by trees of little present or future value. 
Table 1.--Forest and nonforest area by regions, 1947

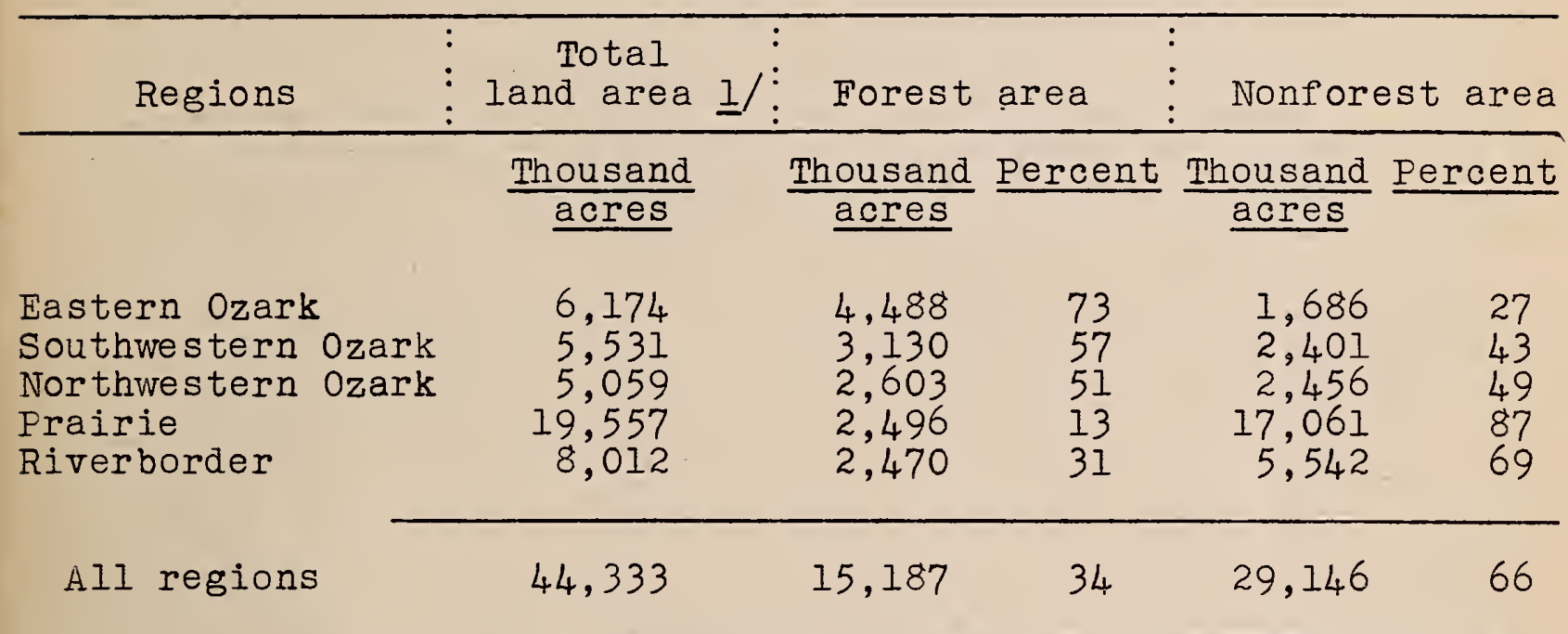

I/ Source: Area of the United States 1940, U. S. Bureau of the Census. 
Table 2.--Commercial forest area by ownership class, 1947

\begin{tabular}{lcc}
\hline \multicolumn{1}{c}{ Ownership class } & $\vdots$ & \multicolumn{2}{c}{ Commercial forest area 1/ } \\
\hline & $\frac{\text { Thousand }}{\text { acres }}$ & Perzent \\
& & \\
$\begin{array}{c}\text { Federal: } \\
\text { National forest } \\
\text { Other }\end{array}$ & 1,197 & 7.9 \\
$\quad$ Total & 121 & .8 \\
\cline { 2 - 3 } State & 1,318 & 8.7 \\
Private & 120 & .8 \\
\multicolumn{1}{c}{ All ownerships } & 13,636 & 90.5 \\
\hline
\end{tabular}

If Does not include 113,000 acres of forest land classified as noncommercial. 
Table 3.--Commercial forest area by forest

type and stand-size class, 1947

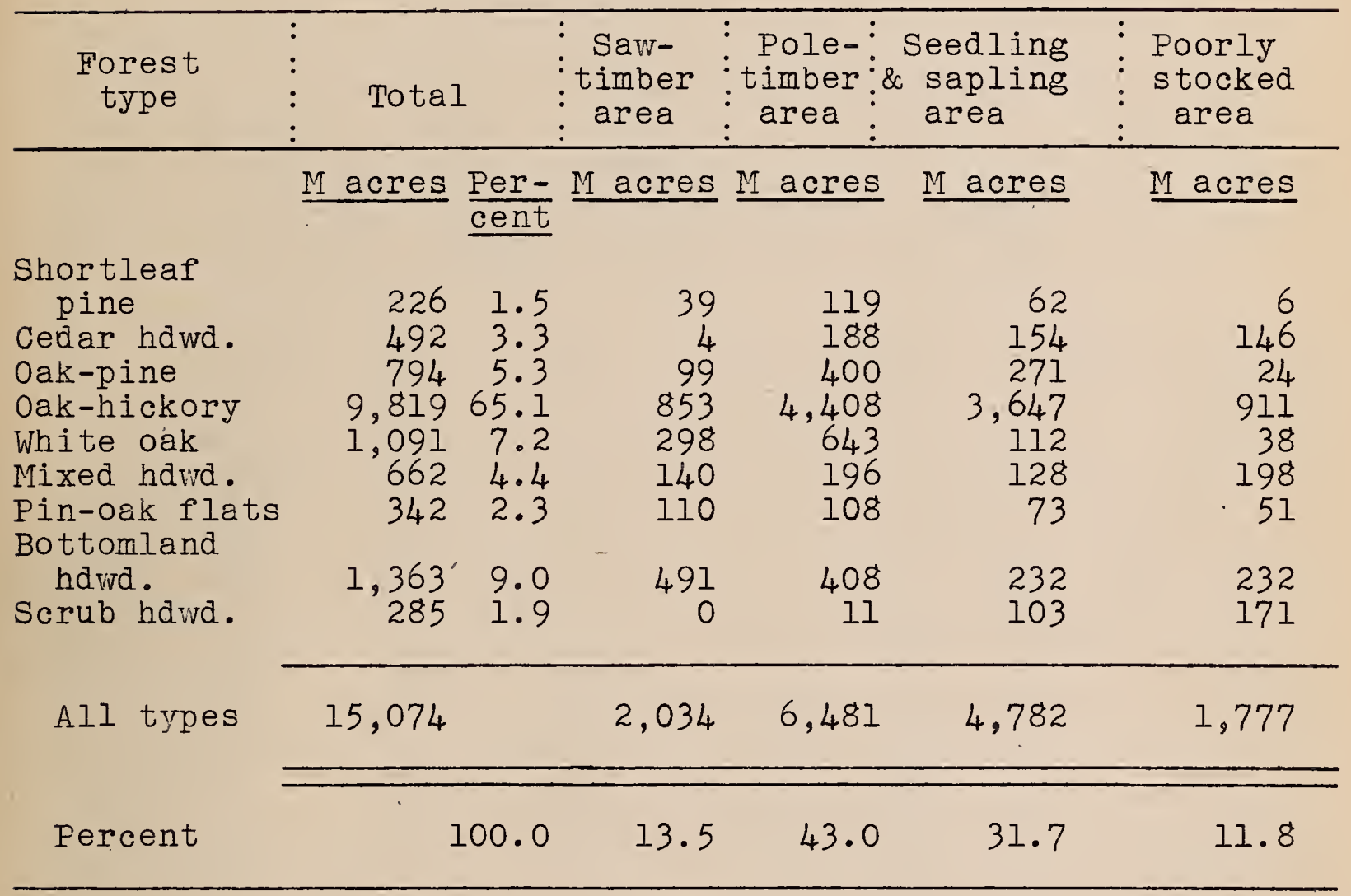


Table 4.--Saw-timber volume on commercial forest area by species and stand-size class, 1947

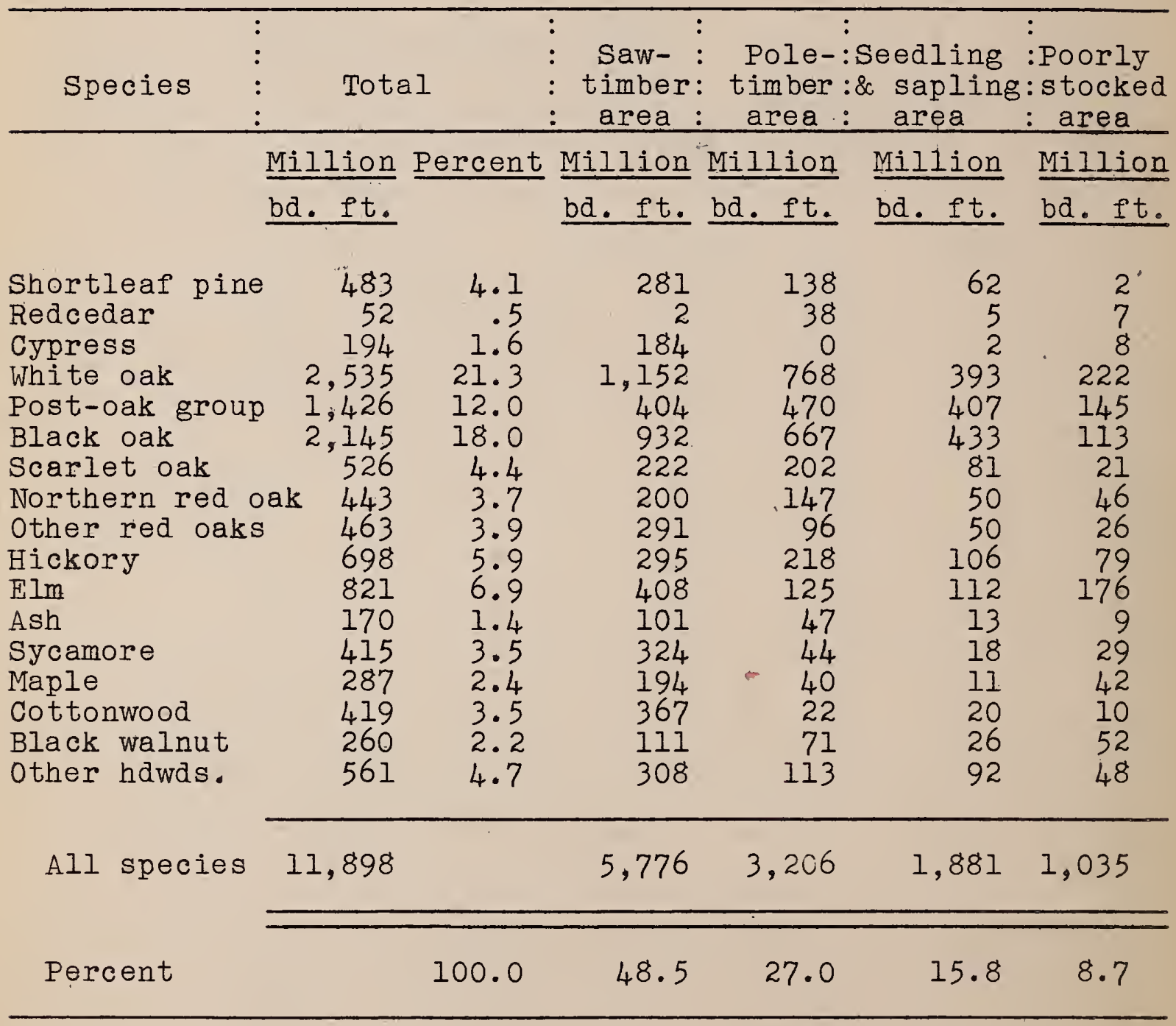


Table 5.--Saw-timber volume on commercial forest area by species and tree-diameter class, 1947

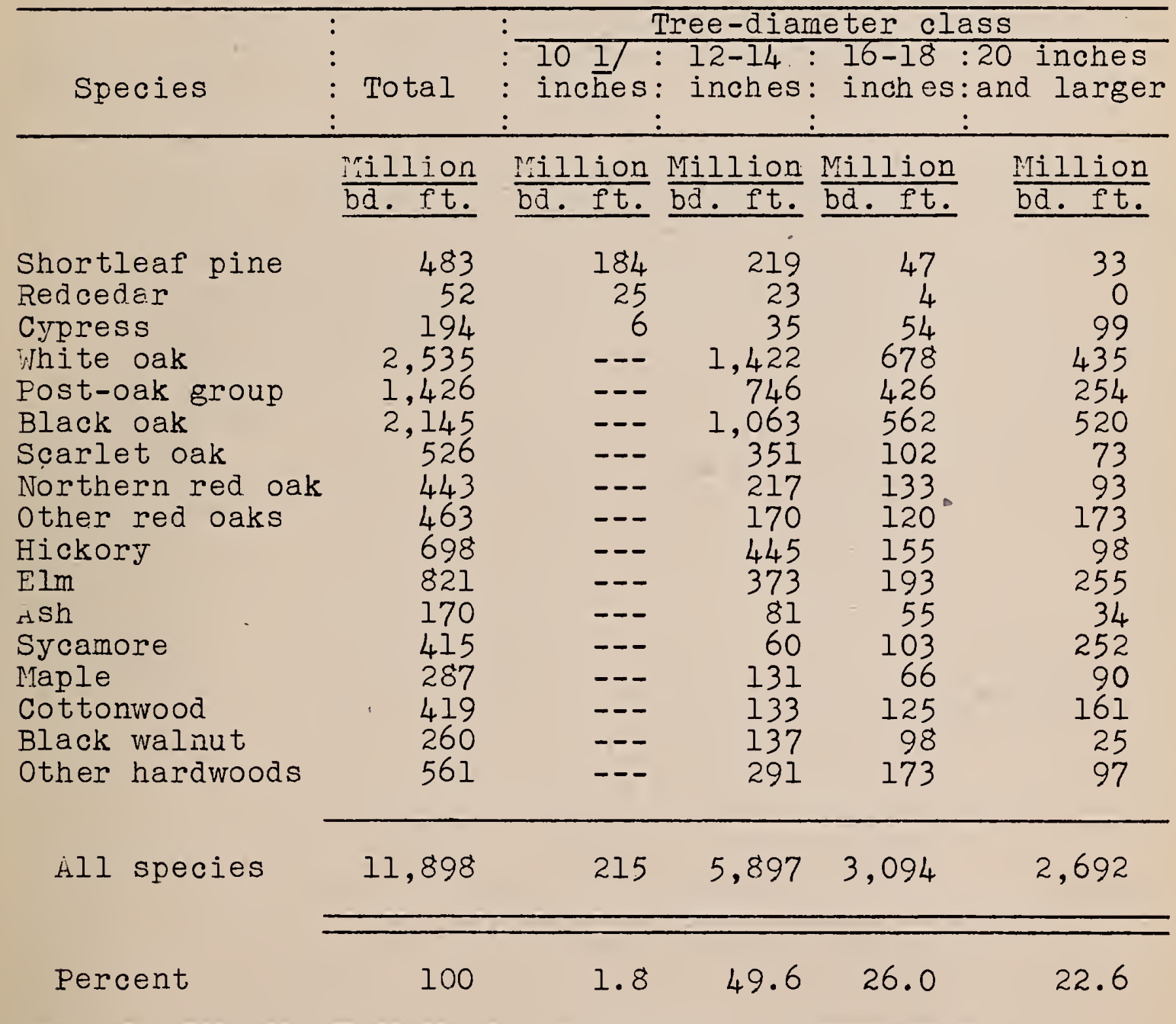

I/ Ten-inch dianeter class shown separately because in this diameter class, saw-timber volume includes softwood trees, but not hardwoods. 
Table 6.--Cubic-foot volume on comercial forest area by species and stand-size class, 1947

\begin{tabular}{|c|c|c|c|c|c|c|}
\hline \multirow[t]{3}{*}{ Species } & \multicolumn{2}{|c|}{ Total } & $\begin{array}{l}\text { Saw- } \\
: \text { timber } \\
: \text { area } \\
\vdots\end{array}$ & $\begin{array}{c}\text { Pole- : } \\
\text { timber: } \\
\text { area : }\end{array}$ & $\begin{array}{l}\text { Seedling } \\
\text { \& sapling } \\
\text { area }\end{array}$ & $\begin{array}{l}\text { Poorly } \\
\text { : tocked } \\
: \text { area }\end{array}$ \\
\hline & \multirow{2}{*}{\multicolumn{2}{|c|}{$\frac{\text { Million }}{\text { cu. ft. }}$}} & Million & Million & Million & \multirow{2}{*}{$\begin{array}{l}\text { Million } \\
\text { cu.ft. }\end{array}$} \\
\hline & & & cu. ft. & cu. ft. & cu. ft. & \\
\hline $\begin{array}{l}\text { Shortleaf pine } \\
\text { Redcedar } \\
\text { Cypress } \\
\text { White oak } \\
\text { Post-oak group } \\
\text { Black oak } \\
\text { Scarlet oak } \\
\text { Northern red }\end{array}$ & $\begin{array}{r}198.1 \\
49.6 \\
41.5 \\
904.2 \\
\mathrm{p} \quad 641.2 \\
763.6 \\
222.0\end{array}$ & $\begin{array}{r}4.5 \\
1.1 \\
1.0 \\
20.8 \\
14.7 \\
17.5 \\
5.1\end{array}$ & $\begin{array}{r}73.8 \\
1.9 \\
39.3 \\
273.2 \\
109.3 \\
199.8 \\
49.7\end{array}$ & $\begin{array}{r}100.4 \\
40.2 \\
0 \\
474.8 \\
350.5 \\
422.3 \\
142.9\end{array}$ & $\begin{array}{r}21.7 \\
3.1 \\
.6 \\
111.9 \\
140.9 \\
118.1 \\
24.1\end{array}$ & $\begin{array}{l}2.2 \\
4 \cdot 4 \\
1.6 \\
44 \cdot 3 \\
40.5 \\
23 \cdot 4 \\
5.3\end{array}$ \\
\hline $\begin{array}{l}\text { oak } \\
\text { Other red oaks } \\
\text { Hickory } \\
\text { Elm } \\
\text { Ash } \\
\text { Sycamore } \\
\text { Maple } \\
\text { Cottonwood } \\
\text { Black walnut } \\
\text { Other hardwood }\end{array}$ & $\begin{array}{r}141.1 \\
144.8 \\
342.0 \\
253.8 \\
54.6 \\
89.7 \\
127.3 \\
94.5 \\
93.7 \\
\text { as } 195.8\end{array}$ & $\begin{array}{l}3.2 \\
3.3 \\
7.8 \\
5.8 \\
1.3 \\
2.1 \\
2.9 \\
2.2 \\
2.2 \\
4.5\end{array}$ & $\begin{array}{r}38.7 \\
59.6 \\
96.8 \\
103.8 \\
25.6 \\
57.5 \\
66.5 \\
72.6 \\
26.5 \\
77.5\end{array}$ & $\begin{array}{r}77.4 \\
67.0 \\
169.5 \\
78.1 \\
21.9 \\
14.4 \\
45.2 \\
17.2 \\
40.4 \\
71.4\end{array}$ & $\begin{array}{r}16.2 \\
8.9 \\
52.7 \\
34.1 \\
4.5 \\
11.3 \\
3.3 \\
3.2 \\
12.4 \\
27.0\end{array}$ & $\begin{array}{r}8.8 \\
9.3 \\
23.0 \\
37.8 \\
2.6 \\
6.5 \\
12.3 \\
1.5 \\
14.4 \\
19.9\end{array}$ \\
\hline All species & $4,357.5$ & & $1,372.1$ & $2,133.6$ & 594.0 & 257.8 \\
\hline Percent & & 100 & 31.5 & 49.0 & 13.6 & 5.9 \\
\hline
\end{tabular}


Table 7.--Cubic-foot volume on commercial forest area by stand-size class and tree-diameter class, 1947

\begin{tabular}{|c|c|c|c|c|c|c|}
\hline 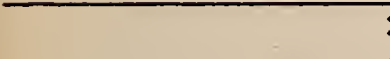 & : & & Tree-di & ameter c & lass & \\
\hline $\begin{array}{c}\text { Stand-size } \\
\text { class }\end{array}$ & Total & : & $\begin{array}{l}10: \\
\text { inches: }\end{array}$ & $\begin{array}{l}12-14: \\
\text { inches: }\end{array}$ & $\begin{array}{l}\text { 16-18 } \\
\text { inches }\end{array}$ & $\begin{array}{l}: 20 \text { inches } \\
: \& \text { larger }\end{array}$ \\
\hline & $\frac{\text { Million }}{\text { cu. ft. }}$ & $\frac{\text { Million }}{\text { cu.ft. }}$ & $\frac{\text { Million }}{\text { cu. ft. }}$ & $\frac{\text { Million }}{\text { cu. ft. }}$ & $\begin{array}{l}\text { Million } \\
\text { cu.ft. }\end{array}$ & $\frac{\text { Million }}{\text { cu.ft. }}$ \\
\hline $\begin{array}{l}\text { Saw-timber area } \\
\text { Pole-timber are }\end{array}$ & $\begin{array}{l}1,372.1 \\
2,133.6\end{array}$ & $\begin{array}{r}211 \cdot 4 \\
1,040.5\end{array}$ & $\begin{array}{l}214.5 \\
561.4\end{array}$ & $\begin{array}{l}388.7 \\
374.5\end{array}$ & $\begin{array}{r}268.3 \\
99.4\end{array}$ & $\begin{array}{r}289.2 \\
57.8\end{array}$ \\
\hline $\begin{array}{c}\text { Seedling \& sap- } \\
\text { ling area }\end{array}$ & 594.0 & 158.9 & 113.3 & 179.5 & 92.6 & 49.7 \\
\hline $\begin{array}{c}\text { Poorly stocked } \\
\text { area }\end{array}$ & 257.8 & 49.4 & 38.8 & 72.6 & 52.8 & 44.2 \\
\hline All classes & $4,357 \cdot 5$ & $1,460.2$ & 928.0 & $1,015.3$ & 513.1 & 440.9 \\
\hline Percent & 100 & 33.5 & 21.3 & 23.3 & 11.8 & 10.1 \\
\hline
\end{tabular}


Table 8.--Average volume per acre by stand-size

class and region, 1947

BOARD-FOOT VOLUNIE

\begin{tabular}{|c|c|c|c|c|c|c|}
\hline $\begin{array}{c}\text { Stand-size } \\
\text { class }\end{array}$ & Total & $\begin{array}{l}\text { Eastern } \\
: \text { Ozark }\end{array}$ & $\begin{array}{l}\text { South- } \\
\text { :western } \\
\text { Ozark }\end{array}$ & $\begin{array}{l}\text { North-: } \\
\text { : } \\
\text { Ozartern }\end{array}$ & Prairie & $\begin{array}{l}\text { River- } \\
\text { border }\end{array}$ \\
\hline \multirow{2}{*}{$\begin{array}{c}\text { Saw-timber area } \\
\text { Pole-timber area } \\
\text { Seedling \& sap- } \\
\text { ling area } \\
\text { Poorly stocked } \\
\text { area }\end{array}$} & $\begin{array}{r}2,840 \\
495\end{array}$ & $\begin{array}{r}2,280 \\
432\end{array}$ & $\begin{array}{r}2,615 \\
541\end{array}$ & $\begin{array}{r}2,428 \\
369\end{array}$ & $\begin{array}{r}3,179 \\
605\end{array}$ & $\begin{array}{r}3,473 \\
594\end{array}$ \\
\hline & $\begin{array}{l}393 \\
582\end{array}$ & $\begin{array}{l}438 \\
531\end{array}$ & $\begin{array}{l}356 \\
398\end{array}$ & $\begin{array}{l}340 \\
515\end{array}$ & $\begin{array}{l}408 \\
724\end{array}$ & $\begin{array}{l}415 \\
767\end{array}$ \\
\hline \multirow[t]{2}{*}{ All classes } & 789 & 691 & 635 & 527 & 1,074 & 1,149 \\
\hline & \multicolumn{4}{|c|}{ CUBIC-FOOT VOLUME } & & \\
\hline \multirow{3}{*}{$\begin{array}{c}\text { Saw-timber area } \\
\text { Pole-timber area } \\
\text { Seedling \& sap- } \\
\text { ling area } \\
\text { Poorly stocked } \\
\text { area }\end{array}$} & $\begin{array}{l}675 \\
329\end{array}$ & $\begin{array}{l}580 \\
318\end{array}$ & $\begin{array}{l}637 \\
289\end{array}$ & $\begin{array}{l}546 \\
272\end{array}$ & $\begin{array}{l}712 \\
406\end{array}$ & $\begin{array}{l}824 \\
390\end{array}$ \\
\hline & 124 & 154 & 103 & 108 & 118 & 117 \\
\hline & 145 & 145 & 110 & 106 & 178 & 191 \\
\hline All classes & 289 & 286 & 227 & 214 & 352 & 390 \\
\hline
\end{tabular}


Table 9.--Total cubic-foot volume of sound wood on commercial forest area by species and class of material, 1947

\begin{tabular}{|c|c|c|c|c|c|}
\hline \multirow[b]{2}{*}{ Species } & \multirow[b]{2}{*}{ Total } & \multicolumn{2}{|c|}{ Sam-timber trees } & \multirow{2}{*}{$\begin{array}{l}\text { Pole- } \\
\text { timber } \\
\text { trees }\end{array}$} & \multirow[b]{2}{*}{$\begin{array}{l}\text { Cull } \\
\text { trees } 2 /\end{array}$} \\
\hline & & Total & $\begin{array}{l}\text { :Sawlog :Tops \& } \\
\text { :portion:limbs I/ }\end{array}$ & & \\
\hline
\end{tabular}

Shortleaf

pine

Redcedar

Cypress

White oak

Post-oak

group

Black oak

Scarlet oak

Northern red

oak

Other red oaks

Hickory

EIm

Ash

Sycamore

Maple

Cottonwood

Black walnut

Other hdwds.

Nonc ommercial

species $\underline{2}$
200.0

50.5

44.2

$1,473.8$

$1,335.8$

$1,338.1$

362.6

265.9

240.2

552.9

579.3

122.9

163.8

262.6

157.8

154.4

391.1
103.1
18.3
40.3
703.3

490.0

628.3

153.1

123.4

131.4

201.7

234.4

47.9

120.3

82.1

117.4

75.0

160.4
86.7

15.6

28.9

405.3

277.2

355.0

86.5

71.1

74.5

114.3

133.2

27.4

68.7

46.6

67.9

42.6

91.3
16.4

2.7

11.4

298.0

212.8

273.3

66.6

52.3

56.9

87.4

101.2

20.5

51.6

35.5

49.5

32.4

69.1
95.0

31.3

1.2

498.9

$364.0 \quad 481.8$

$408.6 \quad 301.2$

$135.5 \quad 74.0$

70.0

70.3

227.7

120.6

27.2

21.0

80.7

26.6

51.1

104.5

1.9

.9

2.7

271.6

72.5

$38: 5$

123.5

224.3

47.8

22.5

99.8

13.8

28.3

126.2
436.3

- -

$-\cdots \quad 436.3$

All species

$8,132.23,430.4 \quad 1,992.8$

$1,437.6$

$2,334.22,367.6$

Percent

$$
100.0
$$

$42.2 \quad 24.5$

17.7

28.7

29.1

1/ Not included in the cubic-foot volumes shown in Tables 6 and 7 excepting the 30.5 million cubic feet in tops of pine, cedar, and cypress.

2/ Not included in the cubic-foot volumes shown in Tables 6 and 7 . 
Forest land - Land bearing forest growth or land from which the forest has been removed but which shows evidence of past forest occupancy and which is not now in other use. To cualify as forest, an area must: (I) be at least 100 feet wide; (2) be at least one acre in area; (3) have a sufficient number of trees to provide 10 percent crown coverage, or (4) lacking 10 percent crown coverage, be likely to remain in forest use.

Commercial forest land - Forest land bearing or capable of bearing tirber of commercial character and economically available now or prospectively for commercial use and not witharawn from such use.

Noncomercial forest land - Forest land not qualifying as cormercial forest land. Two classes of forest area are included: (1) commercially valuable forest land withdrawn from timber use for such purposes as parks, gane refuges, military reservations, or reservoir protection; and (2) forest land which because of poor growing conditions vill not produce trees of comercial cuality.

\section{Forest trpes}

(3)

Shortleaf pine - Stands in which pine trees comprise at least 60 percent of the dominant and codominant trees.

Cedar-hardwoods - Stands in which redcedar comprises at least 20 percent of the dominant and codominant trees.

Oak-pine - Stands of pine, oaks, and other hardwoods in which pines comprise 20-60 percent of the dominant and codominant trees.

Oak-hickory - Stands of hardwoods in which oaks and hickories comprise at least 60 percent of the dominant and codoininant trees.

White oak - Stands in which wite oak (quercus alba) comprises at least 60 percent of the dominant and codominant trees.

Mixed hardwoods - Stands of mixed hardwood species not cualifying for other hardwood types. Frincipal species include elin, maple, basswood, and black walnut in nixture with oaks and hickories. 
Pin-oak flats - Stands of pin oak and other hardwoods occurring on poorly drained flats. Associate species include soft haple, elm, hickory, and sweetgum.

Bottomland hardwoods - Stands on the alluvial bottoms of rivers and streams. The principal species include sycamore, willow, elm, blackgum, sweetgum, soft maple, oaks, hickory, cottonwood, and cypress.

Scrub hardwoods - Stands in which scrub oak or other noncommercial tree species comprise at least 60 percent of the dominant and codominant trees.

Tree classes

Sound saw-timber tree - A coniferous tree at least 9.0 inches d.b.h. (diameter outside bark at 4.5 feet above ground), or a hardwood tree at least 11.0 inches d.b.h., with a sound butt $\mathrm{log}$ at least 8 feet long, or with at least half of the gross volume of the tree in sound material.

Sound pole-timber tree - A tree at least 5.0 inches d.b.h. but less than saw-timber size, which now is or gives promise of becoming a sound merchantablé tree.

Cull tree - A tree that does not qualify as a sound pole-timber or saw-timber tree because of poor form, limbiness, rot, or other defect.

Volume estimates

Board-foot volume - Includes the volume of that portion of saw-tinber trees merchantable for sawlogs. Volume deductions have been made for rot, crook, and other defects. Board-foot volumes are shown in the International 1/4-inch log rule, which approximates green lumber tally.

Cubic-foot volume - Except where specifically noted, includes the volume of sound wood inside bark in:

(1) the saw-timber portion of sound trees, (2) the upper stems of saw-timber-size conifers to a minimum diameter of 4 inches inside bark, and (3) the sound pole-timber trees to the same minimum top diameter.

Stand-size class

Saw timber - Stands having a minimum net volume of

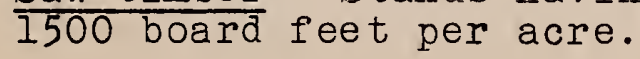


Pole timber - Stancs having a net volume of less than 1500 board feet per, acre but which are at least 10 percent stocked th pole-size and larger trees. At least one-half the minimum stocking must be in polesize trees.

Seedlings and saplings - Stands not qualifying either for saw timber or pole timber but having at least 300 seedlings and saplings of commercial species per acre.

Poorly stocked - Comercial forest land not qualifying for any other class, including denuded area.

Species listed

Shortleaf pine - Pinus echinata. Includes a small volume of other pines occurring in plantations.

Redcedar - Eastern redcedar - Juniperus virginiana

Cypress - Taxodium distichum

White oak - Quercus alba

Fost-oak group includes:

Post oak - Quercus stellata

Swanp white oak - Quercus bicolor

Swamp chestnut oak - Quercus prinus

Overcup oak - Quercus lyrata

Bur oak - Quercus macrocarpa

Chinouapin oak - Quercus muehlenbergii

Black oak - Quercus velutina

Scarlet oak - Quercus coccinea

Northern red oak - Quercus borealis

other red oaks include:

Southern red oak - Quercus falcata

Pin oak - Quercus palustris

Willow oak - Quercus phellos

Water oak - Quercus nigra

Shingle oak - Quercus imbricaria

Hickory - includes all species of hickory (Carya)

Elm - includes all species of eln (Ulmus)

Ash - includes all species of ash (Fraxinus)

Sycamore - Platanus occidentalis 
Maple - includes all species of maple (Acer)

Cottonwood - Fopulus deltoides

Black walnut - Juglans nigra

Other hardwoods - include all other commercial hardwood species.

Nonconmercial species - include species which do not normally have commercial value such as blackjack oak, sassafras, blue beech, ironwood, alder, redbud, and service berry. 


\section{FOREST SURVYY PROCEDURE}

The inventory of the forest resources of Missouri was begun in September 1946 and vas completed in september 1947. A sampling procedure was used involving an office study of aerial photographs and a field examination of randomly selected forest and nonforest plots.

The proportion of forest land by counties was obtained by placing over each photograph a transparent template marked with uniformly spaced dots and counting the number of dots falling on forest and on nonforest areas. The percentage of forest dots in a county applied to the total land area gave a preliminary estinate of the forest acreage.

The location of every second or third dot (depending on the template used) falling on forest land was marked on the photograph. The acre surrounding each marked dot was examined under stereoscope and classified by stand-size class on the basis of the height, crown width, and density of trees on the plot.

Plots for field examination were selected from those photo classified as follows:

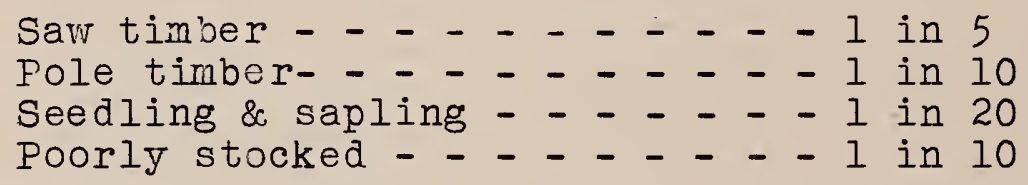

In adition, every 50 th nonforest plot was selected for field examination to measure the movement of nonforest land to forest.

The locations of the selected plots were marked on the photographs which were then sent to the field. Crews of two men each located these points on the ground and at each established a 1/5-acre plot on which they recorded the species, size, condition, and growth rate of trees, and the forest type and site quality of plots. A field check of the photo interpreter's stand-size-class determination was also made. The field examination also provided a basis for adjusting the preliminary estimate of forest and nonforest area.

Approximately 196,590 dots were counted on the photos for forest area deternination. Stereoscopic examinations were made on 26,370 forest plots to determine stand-size class, and 3,489 plots were examined on the ground. These photo and field examinations provided the basic data for computation of forest area and timber volume statistics for the state. 


\section{ACCURACY OF DATA}

Forest area - Statistical analysis of the forest area data for the state of Missouri shows a sampling error of +0.7 percent of the total forest area or $\$ 100,190$ acres, at $\bar{a}$ level of one standard deviation. The error of estimate increases with each subdivision of the total forest area so that small tabular acreages may have large errors and therefore indicate only relative magnitudes.

Timber volume - The samoling error of the total boardfoot volume in the state is $\$ 2.6$ percent or $\$ 315$ million board feet. This does not include the errors of volume tables, cull factors, or other phases of the inventory work for which satisfactory methods of measuring accuracy have not been developed. All phases of field work and computations were closely supervised to keep these errors at a minimum. Again the error of estimate increases with each subdivision of the total volume so that snall volumes indicate only relative magnitudes. 



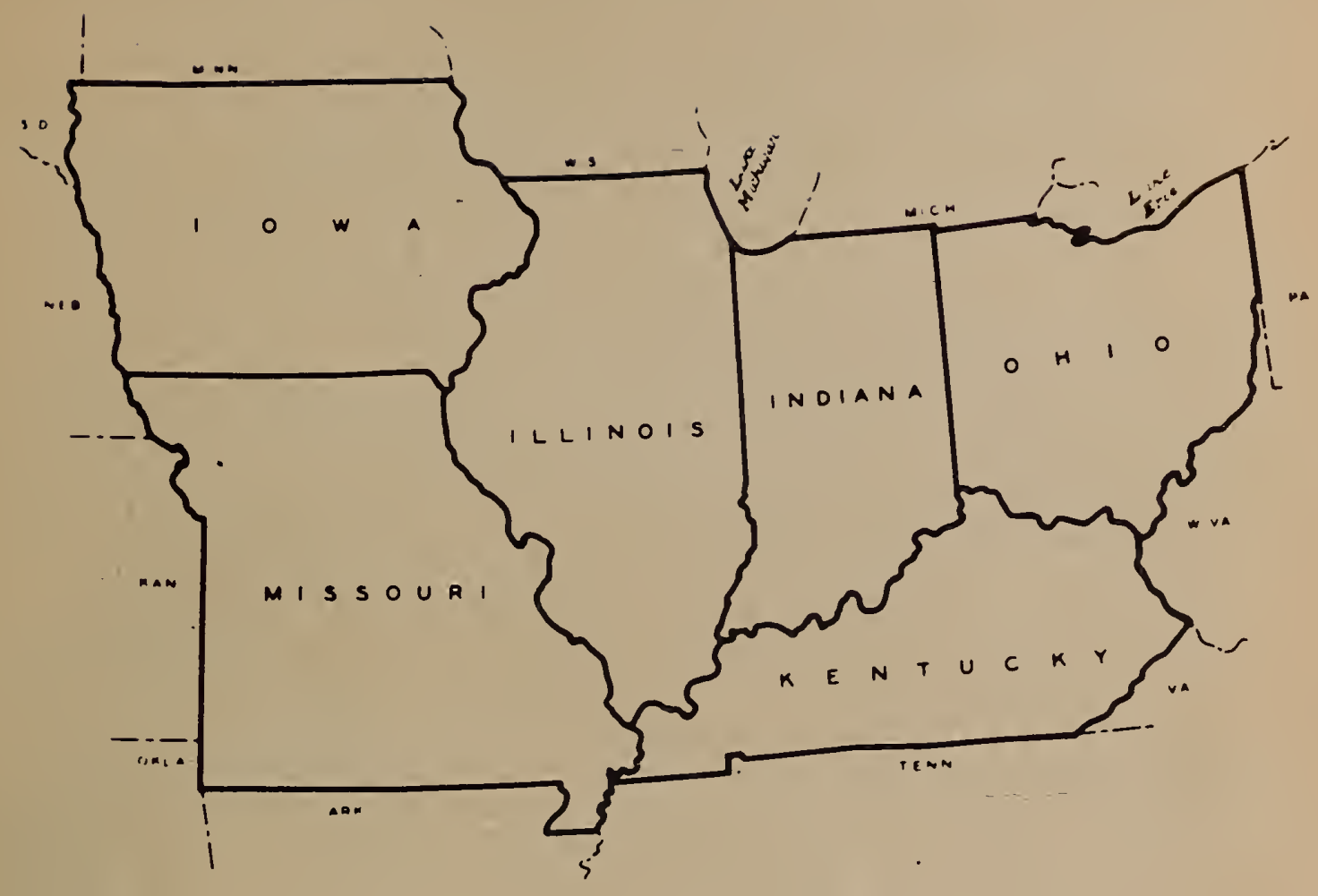

TERRITORY SERVED

BY THE

CENTRAL STATES FOREST EXPERIMENT STATION FOREEST SERVICE

UNITEO STATES DEPARTMENT OF AGRICULTURE . 
